\title{
Managament in Tourism and Environment Protection
}

\author{
Edna Mrnjavac* \\ Branka Berc Radišić* \\ Nadia Pavia*
}

\begin{abstract}
Tourist activities motivate tourists to visit a destination. Tourism evaluates motives and protects them largely from harmful influences. Tourism evaluation aims to establish the value of natural tourist attractions and of those created by humans. Along with tourist attractions, destinations are also evaluated in order to find out about their utility. The evaluation of a destination and its particular attractions is expressed by the realized tourist traffic for the observed period. Protection of tourist attractions is a systematic activity against all kinds of pollution. It also includes the sustainability of traffic flows in tourism destination. Management in tourism industry has an irreplaceable role in that.
\end{abstract}

Key words: tourism, destination, tourist attraction, evaluation, traffic, marketing, management in tourism.

\section{Introduction}

In the last couple of years a growing concern for the effects of human activity on environment is felt. Global warming, acid rains, ozone depletion, and excessive exploitation and pollution of natural land and water resources are seen as main problems. All of these problems concern not only one tourist destination, but the whole world, and they are closely connected to all aspects of tourism.

The importance traffic, its influence on tourism and on marketing objectives actives towards protection of tourist destination role of management in environments protection will be discussed subsequently in this paper.

\section{The role of management in evironment protection}

Managing the changes in tourism and hospitality industry in a way that they simultaneously contribute to economic development and environmental protection is a very demanding task. It became apparent that enterprises in tourism and hospitality industry are capable of measuring planning methods and the increase of quality in their offer.

* Faculty of Tourism and Hospitality Management in Opatija, 51410 Opatija, Ika 42, p.p. 97, Croatia 
Changes in the behavior enterprise towards the environment were significantly affected by development of environmental protection policy, strengthening of ecological consciousness and changes in demands of tourists, introduction of ecological etiquette of the tourism offer, changes in the moral of managers and employees in the tourism and hospitality industry, whose ecological awareness is growing.

Management in tourism is aware that a good ecological image provides competitive advantage. Ecological standpoint has become an important factor in planning of the tourism offer. Therefore, management, besides already traditional criteria in product forming (economy, safety, comfort, functionality, esthetics, etc.) should pay special attention to the offer's influence on the environment.

Aiming to protect the environment, enterprises direct their activities in four fundamental job groups [Črnjar, M., 2002, p. 205]:

- Production and product planning

- Implementation of new technological procedures in the production

- Investing in the environmental protection, and

- Forming of special services for the environmental protection.

All these activities occur in an interactive relation to other activities. Business and production policy is often in conflict with the strategy of modern marketing, which is directed towards the creation of new products.

Special attention should be given to the choice of technologies. The choices should be contemplated from the standpoint of technology's significance for the environment protection.

Development policy of a hotel enterprise should set development trends, time, intensity, methods and the place of development. Such policy should also provide a base for investing in ecological projects and programs.

Ecological protection planning is a complex issue, which should be a part of existing programs of work and development within each enterprise.

It is demanded from management to manage in a way which benefits the society in whole. This especially relates to the quality of tourism offer, safety of employees in tourism and hospitality industry, and the need to protect the environment from negative influence of a product.

In order to estimate relation of management in tourism and hospitality industry towards ecological protection, its activity is being analyzed. The analysis should provide answers to the following questions [Črnjar, M., 2002, p. 210]:

- What lead management to act accordingly with ecological recommendations and standards?

- How is management implementing ecological standards in managing?

- Are economic goals of a enterprise in absolute advantage towards ecological goals?

- How much is invested in ecological protection and how are ecological expenses monitored?

- How is influence of ecological protection policy on business monitored and analyzed?

The relation of a certain enterprise towards the environment through its policies and business goals is valued increasingly. Consequently, particular activities, production and services are being conducted in accordance with the principles, which provide a positive relation towards the environment. Management must not only formally recognize ecological laws but also set acceptable economic development and expenses of ecological protection.

The tourism enterprises, regardless of their size or offered services, provide a negative influence on the environment. Whilst aiming to provide adequate services for tourists, it has 
become huge consumers of natural resources: energy, water, materials, space. By doing so, hotels use harmful substances and also directly produce waste and polluting emissions.

The role of management is especially significant in projecting or improvement of production processes. Management should consider the question of creation and waste reduction, waste danger, and economic justification of participating in activities which target solving of waste issues.

Management in tourism and hospitality industry will increasingly face complex ecological regulations. As a result, the management will have to actively participate in public ecological protection in the future and develop a program of ecological protection. Of the same importance will be the task of management to analyze production process to increase eco-efficiency.

Tourism evaluation of a destination and its particular attractions is expressed by the realized tourist traffic for the observed period. Tourist traffic in Croatia is gradually growing. In 2007, upward of 11 million tourists visited Croatia and 56 million overnights were realised. In recent years, there has been a significant increase in the number of overnights. For example, the number of overnights in 2007 increased by 5.7 percent in comparison to 2006 , and by as much as 42.5 percent in comparison to 2000 . However, the number of overnights realised in the years prior to the Patriotic War has yet to be reached.

Table 1: Number of arrivals and overnights in the 2000 - 2007 period

\begin{tabular}{|l|r|r|}
\hline & Tourist overnights & \multicolumn{1}{|c|}{ Tourist Arrivals } \\
\hline 2000 & $39,283,854$ & $7,136,554$ \\
\hline 2001 & $43,404,354$ & $7,859,757$ \\
\hline 2002 & $44,692,450$ & $8,320,200$ \\
\hline 2003 & $46,635,150$ & $8,878,000$ \\
\hline 2004 & $47,797,300$ & $9,412,300$ \\
\hline 2005 & $51,420,948$ & $9,995,070$ \\
\hline 2006 & $53,066,946$ & $10,384,921$ \\
\hline 2007 & $56,005,492$ & $11,162,406$ \\
\hline
\end{tabular}

Source: State Institute for Statistics

Tourism is one of the most significant economic activities, so it is only reasonable to ensure such transport links that will have a positive influence on tourism and help to represent tourist destination as within reach.

\section{Traffic as part of the tourism destination offer}

Main resource that influences the attraction tourism destination Republic of Croatia and determines the structure and volume of demand for transport services is the vicinity to the emitive market. This vicinity conditions the absolutely dominant role of road transport which makes up 99.4 per cent of transport, while the share of other transport means is negligible; railway transport merely 0.4 per cent, air transport 0.1 per cent and maritime transport 0.1 per cent [Institut za turizam, Tomas 2001, p.133].

The vicinity of a destination alleviates the decision making about setting out on a journey and induces more frequent traveling. These trips need not last long, but the easiest way to organize them is by car. This abnormally big share of road transport used by tourists (which 
is even above the Croatian standard) might endanger natural resources, since it is particularly road transport that has the most aggressive and negative impact on the environment. Supervision should follow the developing trend of tourist transport, by monitoring shares of different transportation branches in tourist flows, ecological parameters on main traffic flows and in settlements, as well as other unfavorable phenomena that are caused by road transport.

Although creation and implementation of traffic policy is in state jurisdiction, it is up to tourism enterprises to define and articulate the traffic needs due to tourism demand. The aim of tourism management is to detect the amount and characteristics of tourist-traffic demand in order to create an integral product of tourism destination. This makes possible to cooperate with those in charge for traffic policy creation and implementation on, and to ask for such traffic solution which are environmental friendly as well as capable to meet all tourism needs.

According to the needs of tourism development, there should be a better solution for traffic in cities and settlements, since it is exactly in these micro locations due to heavy traffic during summer months that all the negative characteristics of road transport are evident. This may result in unsatisfied visitors. Streets free of traffic congestion, adequate approach to main highways, enough parking space, usage of ITS for tracking and a more effective utilization of existing infrastructure and regulation of traffic flows, keeping trucks outside of settlements, closing city cores for road transport, creating pedestrian precincts in parts particularly interesting to visitors are main points for the integral organization of traffic in a city or a settlement - tourist destination.

So called „ecology"traffic systems have a considerable high potential in tourism flows, because they use other modes of power such as: electric, hybrid, alcohol, metan etc. The possibilities of these traffic modes (for example cableways, ropeways, panoramic railways, bicycles, cars, buses, etc) are without frontiers taking into consideration dynamic capacity, location (underground, on the surface, a combination of both and so on), minimal environmental devastation and area occupied, high level of reliability and atractivity of traffic service.

Objectives which the traffic system of counties tourist destination should be aiming at can be hierarchically differentiated into general and specific. The group of general objectives is in accordance with developmental goals of the traffic system. Therefore, the realization of these is closely linked to the realization of traffic system development. Specific objectives reflect particular developmental needs of the transport system in traffic.

General objectives of traffic system development in the function of tourism. Traffic capacities are not used only by one homogenized group of users; instead they are available to all regardless of their traveling motives. In the organization process of a traffic system that should satisfy tourists' needs, one should first of all satisfy some basic criteria that arise from specific features of transport. Therefore, the most important objectives of traffic system [The above mentioned objectives comprise the objectives defined by the Physical plan of PGC, Book 2, p. 117]:

- inclusion of all transportation branches and the accompanying infrastructure into a functional and efficient unit;

- compatibility with the Croatian traffic system;

- compatibility with the European traffic system;

- establishment of an optimal network of international and national traffic corridors and local traffic lines in order for the working up of traffic infrastructure to follow developmental plans;

- creation of an optimal structure of equally represented traffic branches, as well as the improvement of maritime and railway transport; 
- defining strategies and policies of traffic safety, for all direct and indirect participants that can prevent the expansion of a number of accidents (not only the police);

- introduction of ITS (intelligent transportation systems) in order to be able to use traffic infrastructure capacities, safety enhancement and reduction of pollution;

- monitoring pollution caused by traffic, creating concepts for sustainable development and its gradual realization;

- introducing ecologically acceptable transportation means;

- organizing city traffic with reference to positive experiences of numerous cities of the EU;

- creating traffic nodes and roundabouts around cities and settlements in order to attain a more efficient linking of traffic flows.

Once the general objectives are accomplished, a modern traffic system of tourist destination will be created and this system will optimally satisfy all tourists' needs and the needs of a particular region.

Specific objectives of traffic system development in the function of tourism. In order for the traffic to satisfy tourism needs, the group of general objectives is especially important for satisfying specific traffic projects designed for tourists. Specific objectives represent a concretization of some general objectives in order to satisfy specific tourist' needs in the best possible way.

Special attention should be given to traffic solutions that have a small influence on the environment, which satisfy the needs of tourists and other users from the quantitative point of view, and can act as a motive of attraction for a tourism destination. Therefore it is up to tourism management to research and articulate tourism demand according to the optimal traffic mode as a factor of attraction and growth of tourism traffic without further environment devastation.

\section{Marketing activities for the preservation of a tourist destination}

The development of tourism and hotel business depends to a great extent on the environment, more than any other trade does. The preservation of natural and cultural values ensures that a particular destination will be attractive for tourists. The expansive development of tourism after WW II has lead to unfavorable consequences on environment in many countries, Croatia being one of them. Negative effects were aided by an uncontrolled expansion of industry and urbanisation.

However, effects were not the same in all regions attractive for tourism. They depended upon many factors [Jovičić, T., Jovičić, Ž. Ivanović, V., 2005, p. 217]:

- appearance of accommodation capacity,

- attractiveness of cultural and natural objects,

- number of visitors,

- transportation means used by visitors,

- development of tourist trade management and environment management,

- behavior of visitors and their awareness of the impact they leave on the environment and therefore their impact on the development of tourist offer in the area. 
Tourism undoubtedly connects urban areas with well protected natural attractions. It validates certain qualities of the area which are of marginal importance for other trades.

Only tourism can signify climate, flora, fauna, caves, coasts, and other natural objects.

Tourism is a specific user of the destination area, and its effects are not irreversible. In a self sustaining system, it elevates and dignifies the area.

Protected natural and cultural values, like National parks, Nature parks, and archeological locations represent attractive motives for tourists. Along with their promotion, awareness is raised about the necessity to protect them and to preserve the value of a tourist destination.

A significant flow of tourists is realised in tourism facilities, natural and cultural attractions of a particular destination. A part of the financial means acquired at these locations is invested into environment protection and nature preservation.

So, tourism has an interest in natural and cultural values protection and preservation, since its business is largely based on them.

Today in Croatia 775 natural resorts, or 7,9 per cent of sustainable territory is protected; this includes 7 National parks, 6 Nature parks and 70 special reservations. Plitvice Lakes National Park and the region of Velebit are included on UNESCO's world heritage list.

The monument heritage list of the Republic of Croatia includes 15 thousand objects and locations. Those are: archeological findings, urban and rural parts, and individual objects. Regions of Dubrovnik, Split, Trogir and Poreč with their particular resorts are also included on UNESCO's world heritage list [Tourism dictionary, 2001].

Advocators of environment protection are fighting the impact that marketing has on the environment and service expenses that consumer's demands and wishes bring along. Streams of organised citizens and government agencies in Croatia, as in the rest of the world, are not generally against marketing and market demand; they only expect the businesses to take better care of the environment. Goal of marketing is not highest demand on the market, but a high quality of life of the local population, as well as that of tourists. The quality of life does not only refer to the quality of goods and services, but also to the quality of the environment [Kotler P. and others, 2006, p. 184].

Tourism, when using natural and cultural values, or a particular destination area should heed regulations for protection and exploitation, which are:

- rational use of the area and values,

- efficient implementation of environment protection,

- investing means from tourism to improve environment protection,

- setting up sustainable offer capacity and developing adequate tourism forms,

- preventive influence on visitors in order to protect the environment by means of tourism and hotel promotion.

\section{Conclusion}

The vicinity of a destination alleviates the decision making about setting out on a journey and induces more frequent traveling. These trips need not last long, but the easiest way to organize them is by car. This abnormally big share of road transport used by tourists (which is even above the Croatian standard) might endanger natural resources, since it is particularly road transport that has the most aggressive and negative impact on the environment.

So called "ecology" traffic systems have a considerable high potential in tourism flows, because they use other sources such as: electric, hybrid, alcohol, metan etc. The possibilities 
of these traffic modes (for example cableways, ropeways, panoramic railways, bicycles, cars, buses, etc are without froniers taking into consideration dynamic capacity, location (underground, on the surface, a combination and so on), minimal environmental devastation and area occupied, high level of reliability and atractivity of traffic service.

Objectives which the traffic system of counties tourist destination should be aiming at can be hierarchically differentiated into general and specific. The group of general objectives is in accordance with developmental goals of the traffic system. Therefore, the realization of these is closely linked to the realization of traffic system development. Specific objectives reflect particular developmental needs of the transport system in traffic.

The aim of tourism management is to detect the amount and characteristics of tourist and traffic demand in order to create an integral product of tourism destination. This makes possible to cooperate with those in charge for traffic policy creation and implementation on, and

to ask for such traffic solution which are environmental friendly as well as capable to meet the tourism needs.

\section{Reference}

Berc Radišić, B.,(2005): Promocija u hotelijerstvu, Fakultet za turistički i hotelski menadžment u Opatiji, Opatija

Črnjar, M.,(2002): Ekonomika i politika zaštite okoliša, Ekonomski fakultet Sveučilišta u Rijeci i Glasa Rijeka, Rijeka

Green Paper - Towards a Future Maritime Policy for the Union (2006): A European Vision for the oceans and Seas, Commission of the European Communities, Brussels

Institut za turizam, (2002): Stavovi i potrošnja turista u Hrvatskoj - Tomas 2001, Zagreb

Jovičić, T., Jovičić, Ž., Ivanović, V., (2005): Osnove turizma, «Plana tours», Beograd

Kotler, P. and etc., (2006): Osnove marketinga, Zagrebačka škola ekonomije i menadžmenta, Mate, Zagreb

Medlik, S., Ingram, H., (2002): Hotelsko poslovanje, Golden marketing, Zagreb

Mrnjavac, E., (2006): Promet u turizmu, Fakultet za turistički i hotelski menadžment u Opatiji, Opatija

Tourism dictionary, (2001): Masmedija, Zagreb 